\title{
PENGARUH MODEL PEMBELAJARAN JIGSAW TERHADAP HASIL BELAJAR BERBICARA SISWA KELAS IV SDI TETEBATU KABUPATEN GOWA
}

\author{
Abdul Munir \\ Fakultas keguruan dan Ilmu Pendidikan, Universitas Muhammadiyah Makassar \\ abdul.munir@unismuh.ac.id
}

\begin{abstract}
Abstrak
Tujuan penelitian ini adalah mengungkap dan menganalisis, Pengaruh Jigsaw, terhadap hasil belajar berbicara bahasa Indonesia. Metode eksperimen yang digunakan adalah Desain Penelitian Posttest Only Desain. Adapun populasi sebanyak 86, sampelnya 43. Instrument penelitian adalah lembar observasi, objektif tes (pilihan ganda), dan format wawancara, serta dokumentasi. Hasil analisis data menunjukkan bahwa siswa yang diberi perlakuan model pembelajaran Jigsaw, memeroleh nilai hasil belajar Berbicara bahasa Indonesia rata-rata baik.
\end{abstract}

Kata Kunci: Pengaruh, Model Jigsaw, Keterampilan Berbicara, bahasa Indonesia, Hasil Belajar.

\begin{abstract}
The purpose of this study is to reveal and analyze, Effect of Jigsaw, the learning outcomes speak Indonesian. Experimental method used is Design Research Posttest Only design. The population of as many as 86 , the sample is 43 . Instrument of research is observation sheet, an objective test (multiple choice), and the format of the interview, and documentation. The result showed that students treated learning model Jigsaw, obtain the value of learning outcomes Indonesian Speaking average good.
\end{abstract}

Keywords: Effect, Model Jigsaw, Speaking Skills, Indonesian, Learning Outcomes.

\section{PENDAHULUAN}

Penelitian ini dilakukan untuk mengukur hasil belajar siswa pada aspek keterampilan Berbicara bahasa Indonesia, Fokus ini adalah kemampuan menggunakan bahasa dalam bentuk komunikasi lisan. Pembelajaran keterampilan Berbicara bahasa Indonesia merupakan salah satu aspek keterampilan berbahasa yang wajib diberikan di sekolah dasar dan berfungsi mengembangkan keterampilan dan kemampuan Berbicara bahasa Indonesia secara baik dan benar, serta mengembangkan kemampuan siswa berkomunikasi melalui lisan.

Penelitian ini terinspirasi oleh hasil belajar siswa berbicara bahasa Indonesia masih kurang opkelompokal. Adapun fokus kajian penelitian yang saya ajukan, adalah keterampilan berbicara bahasa Indonesia secara baik dan benar. Dari sekian peneliti sebelumnya, hanya menyorot satu aspek selain berbicara.

Permasalahan yang muncul adalah apakah ada pengaruh model Jigsaw, terhadap pembelajaran keterampilan berbicara bahasa Indonesia, siswa kelas IV Sekolah Dasar Inpres Tetebatu di Kabupaten Gowa.

Masalah utama dalam penelitian ini berkaitan dengan model pembelajaran adalah sebagai berikut: (1) model pembelajaran yang digunakan oleh guru tidak bervariasi dan kurang menarik, serta tidak menyenagkan, (2) model pembelajaran yang dipilih oleh guru kurang sesuai dengan karakteristik siswa, (3) model pembelajaran yang dilakukan oleh guru berpusat pada siswa tetapi tidak disertai penjelasan yang tuntas, dan (4) penerapan model pembelajaran tidak memperhatikan tingkat kesulitan yang dialami oleh siswa.

\section{TELAAH PUSTAKA}

a. Pendidikan Dasar

Pendidikan dasar berfungsi menanamkan nilai-nilai, sikap dan rasa keindahan, serta memberikan dasar-dasar pengetahuan, kemampuan, dan kecakapan membaca, Berbicara, dan berhitung serta kapasitas belajar siswa untuk melanjutkan kependidikan menengah, dan untuk bekal hidup di dalam bermasyarakat, sesuai dengan tujuan pencapaian pendidikan nasional Bab IV, bagian 1, pasal 12 ayat 1 .

Bahasa merupakan alat untuk berkomunikasi dan komunikasi berlangsung dalam interaksi sosial. Interaksi dan komunikasi sosial dalam kegiatan peer group (kelompok sebaya) mempercepat perkembangan kemampuan 
berbahasa siswa usia SD. Perkembangan kemampuan berbahasa pada usia ini, dipercepat dengan penggunaan media komunikasi baik dalam pembelajaran di kelas, maupun dalam kehidupan sehari-hari.

\section{b. Model Jigsaw}

Model Jigsaw, atau pembelajaran kelompok dikembangkan secara asli oleh David Devries dan Edward (dalam Asri, 2011). Pada Jigsaw siswa memainkan peran belajar kelompok ahli dengan anggota-anggota kelompok lain untuk memeroleh tambahan poin untuk skor kelompok mereka. Jigsaw dapat digunakan dalam berbagai macam mata pelajaran termasuk mata pelajaran bahasa Indonesia. Model pembelajaran Jigsaw, siswa dibagi dalam kelompok belajar yang terdiri atas, empat orang yang memiliki tingkat kemampuan yang berbeda, jenis kelamin, latar belakang etnis. Guru menyajikan mata pelajaran, kemudian siswa bekerja pada kelompok mereka untuk memastikan bahwa semua anggota kelompok telah menguasai pelajaran, melalui kuis.

\section{c. Pembelajaran keterampilan Berbicara}

Keterampilan berbicara lebih mudah diajarkan apabila pembelajar memperoleh kesempatan untuk mengomunikasikan sesuatu secara alami kepada orang lain, dalam kesempatan yang bersifat informal. Selama kegiatan belajar di sekolah, guru menciptakan berbagai lapangan pengalaman yang memungkinkan siswa mengujicobakan keterampilan berbicara dengan menyajikan informasi, berpartisipasi dalam diskusi, dan bentuk-bentuk percakapan untuk menghibur atau menyajikan pertunjukan (Ross dan Roe dalam Rofi'uddin dan Darmiyati, 1988/1999). Program keterampilan berbicara harus dapat memberikan kesempatan pada setiap siswa untuk mencapai tujuan yang dicita-citakan. Menurut Sannang (1985) mengemukakan empat hal yang penting diperhatikan dalam proses belajar-mengajar keterampilan berbicara adalah sebagai berikut:

1) Mudah dan lancar (fasih). Hal ini berarti bahwa setiap siswa harus mendapat kesempatan yang besar untuk berlatih berbicara sampai siswa mampu mengembangkan keterampilan berbicara secara wajar, lancar, dan menyenangkan, baik di dalam kelompok kecil maupun dihadapan umum. Para siswa diharapkan mengembangkan kepercayaan diri untuk tumbuh melalui latihan berbicara.

2) Kejelasan. Hal ini berarti bahwa agar siswa dapat berbicara dengan tepat dan jelas, baik artikulasi, diksi, maupun struktur kalimatnya, gagasan yang disampaikannya, tersusun secara runtut. Untuk melatih kejelasan itu sedapatnya melalui latihan memahami aneka jenis iklan, cerita, puisi, dan novel.

3) Bertanggung jawab. Hal ini berarti bahwa melalui latihan berbicara, siswa dibina dan ditumbuhkan sikap bertanggung jawab, dalam artian apa yang hendak diucapkan atau dibicarakan harus dipikirkan dengan sungguhsungguh. Latihan yang demikian akan menghindarkan siswa dari kebiasaan berbicara yang tidak bertanggung jawab atau kesukaan bersilat lidah dengan memanifulasi kebenaran.

4) Membentuk pendengaran yang kritis. Hal ini berarti bahwa latihan berbicara yang baik sekaligus mengembangkan keterampilan menyimak secara tepat dan kritis. Pada bagian ini, siswa perlu belajar untuk dapat mengevaluasi kata-kata, tujuan pembicaraan dan secara implisit mengajukan pertanyaan, siapakah yang berkata itu?, mengapa ia berkata demikian?, apakah tujuannya?, apakah kewenangannya ia berkata begitu?, dan sebagainya.

Ada sejumlah anggapan yang mendasari pembelajaran keterampilan berbicara, yaitu (1) keterampilan berbicara sangat penting dalam berkomunikasi, (2) keterampilan berbicara adalah suatu proses yang kreatif, (3) keterampilan berbicara adalah hasil proses belajar (belajar dalam arti memperoleh dan belajar secara formal), (4) keterampilan berbicara sebagai media untuk memperluas wawasan, dan (5) keterampilan berbicara dapat dikembangkan dengan berbagai topik (Tarigan, 2008: 9).

Anggapan diatas menjadi dasar tujuan dalam pembelajaran keterampilan berbicara. Tujuan pembelajaran keterampilan berbicara yang dimaksud yaitu agar siswa mampu (1) memilih dan menata gagasan dengan penalaran yang logis dan sistematis, (2) mengungkapkan ide ke dalam bentuk-bentuk tuturan sesuai dengan kaidah bahasa Indonesia yang berlaku, (3) mengungkapkan gagasan dengan jelas dan lancar, dan (4) memilih ragam bahasa Indonesia dengan konteks penggunaanya (Syafi'ie dan Subana, 1993: 36).

Menurut pendapat Lado (dalam sannang, 1985) mengemukakan bahwa Berbicara adalah 
meletakkan atau mengatur simbol-simbol grafis yang menyatakan pemahaman suatu bahasa sedemikian rupa sehingga orang lain dapat membaca simbol-simbol grafis itu, sebagai bagian dari penyajian satuan-satuan ekspresi bahasa.

Berdasarkan pendapat Poerwadarminta (1979) menyatakan bahwa berbicara selalu berurusan dengan bahasa. Hanya bahasalah satu-satunya rumusan untuk Berbicara, itulah sebabnya kecakapan menggunakan bahasa merupakan bekal utama. Selanjutnya Tarigan (2007) mengemukakan pula bahwa berbicara merupakan salah satu keterampilan berbahasa yang digunakan untuk berkomunikasi secara langsung, atau tatap muka dengan orang lain.

\section{d. Hipotesis Penelitian}

Berdasarkan teori-teori yang di kemukakan pada kajian pustaka, maka penulis mengemukakan hipotesis sebagai berikut: Ada pengaruh model Jigsaw, terhadap hasil belajar berbicara bahasa Indonesia siswa kelas IV SD Inpres Tetebatu.

\section{METODE PENELITIAN}

Metode yang digunakan dalam penelitian ini adalah metode eksperimen,yang merupakan bagian dari jenis penelitian kuantitatif. Dipilihnya metode eksperimen ini adalah untuk menguji secara benar hipotesis yang menyangkut pengaruh model pembelajaran terhadap hasil belajar Berbicara berbahasa Indonesia.

Variabel-Variabel yang diteliti pada penelitian ini adalah Variabel terikat yang berupa hasil belajar keterampilan berbicara bahasa Indonesia. Hasil belajar yang dimaksud pada penelitian ini adalah skor yang diperoleh siswa ketika menjawab tes (post-test). Adapun perlakuan yang diberikan pada penelitian ini adalah pembelajaran dengan menerapkan model Jigsaw.

Penelitian ini dilakukan dengan menggunakan desain eksperimen posttest only desain. Perlakuan yang diberikan adalah untuk menyajikan model pembelajaran yaitu model Jigsaw. Rancangan penelitian ini dapat dilihat pada tabel 3.3 sebagai berikut:

Tabel 1. Desain Penelitian Posttest Only Desain

\begin{tabular}{|lll}
\hline E1 & T1 & O1 \\
\hline
\end{tabular}

Keterangan :

$\mathrm{E}_{1} \quad=$ Kelas eksperimen 1
$\mathrm{T}_{1}=$ Perlakuan pada kelompok eksperimen

1

$\mathrm{O}_{1}=$ derajat hasil belajar berbahasa Indonesia setelah diberikan perlakuan model pembelajaran kooperatif tipe Jigsaw.

Sesudah waktu pemberian perlakuan, selama 12 x 35 menit, berakhir, kelompok (kelas) subjek diberi posttes. Posttest terdiri atas 10 item disediakan waktu untuk mengerjakan 2 x 35 menit.

Populasi adalah keseluruhan subjek penelitian, yang meliputi semua elemen yang ada dalam wilayah penelitian, Arikunto (2010:173). Populasi penelitian ini, adalah keseluruhan siswa kelas IV SD Inpres Tetebatu di Kecamatan Pallangga. Anggota populasi memiliki kemampuan akademik yang sama. Kemampuan akademik yang dimaksud adalah berdasar pada prestasi sekolah secara umum.

Tabel 2. Populasi Penelitian

\begin{tabular}{cccc}
\hline Sekolah Dasar & \multicolumn{2}{c}{ Kelas IV } & Jumlah \\
\hline Inpres Tete Batu & IVa. 43 & IVb. 43 & 86 \\
\hline Sumber : SD Inpres Tetebatu & Kecamatan Pallangga Gowa.
\end{tabular}

Penentuan jumlah sampel dilakukan dengan cara undian. Cara undian dilakukan dengan jalan membuat gulungan-gulungan kertas yang berisi semua nomor dari anggota populasi, dan kemudian melakukan undian sebanyak jumlah sampel yang dibutuhkan.Winarsunu.T (2004:1718). Setelah cara undian ini dilakukan, maka yang keluar adalah kelas IV SD Inpres Tetebatu yaitu kelas IVa.

Tabel 3. Sampel penelitian

\begin{tabular}{cc}
\hline Sekolah Dasar & Kelas \\
\cline { 2 - 3 } & IVa \\
\hline Inpres Tetebatu & 43
\end{tabular}

Sumber: Hasil Undian, 2016

Ada tiga bentuk instrument yang digunakan dalam penelitian ini mengukur pengaruh model pembelajaran Jigsaw pada siswa kelas IVa SD Inpres Tetebatu Kabupaten Gowa. Instrumen pertama adalah bentuk tes, lembar observasi, serta dokumentasi penelitian.

Pengumpulan data pada penelitian ini, dilaksanakan melalui langkah-langkah sebagai berikut: (1) Format wawancara, digunakan, untuk menemukan permasalahan yang harus diteliti, dan untuk mengetahui hal-hal dari responden, teknik ini digunakan sebagai studi pendahuluan; (2) Tes, digunakan untuk mengukur kemampuan 
dasar dan pencapaian hasil belajar atau prestasi. Tes yang digunakan adalah tes buatan peneliti yang sudah divalidasi dengan cara berkonsultasi dengan pakar evaluasi pembelajaran; (3) Observasi dan Dokumentasi, digunakan untuk mencari dan mengamati variabel yang telah ditentukan pada kegiatan pelaksanaan pembelajaran.

Kegiatan dalam langkah persiapan Dalam teknik analisis data antara lain : (1) mengecek nama dan identitas siswa; (2) mengecek kelengkapan data, artinya memeriksa isi intrumen pengumpulan data; (3) mengecek macam isian data, hal ini dilakukan jika, di dalam instrument atau beberapa data yang diisi "tidak tahu" atau isian lain yang tidak dikehendaki peneliti, padahal isian yang diharapkan adalah IVariabel pokok, maka item perlu didrop.

Data diolah dan dianalisis dengan mempergunakan fasilitas computer program SPSS Versi 15.0 for windows.

Pengujian hipoetsis nol (HO) dilakukan pada taraf signifikansi 5\%. Adapun data yang dianalisis adalah pengaruh model pembelajaran Kooperatif-Jigsaw, terhadap hasil belajar keterampilan Berbicara bahasa Indonesia.

Pengujian hipotesis statistik dalam penelitian ini dengan menggunakan notasi sebagai berikut:

Hipotesis:

$$
\begin{array}{ll}
\text { Ho } & : \mu A 1 \leq \mu A 2 \\
\text { H1 } & : \mu A l>\mu A 2
\end{array}
$$

\section{HASIL DAN PEMBAHASAN}

Berdasarkan hasil penelitian, pada bab ini secara berturut-turut dipaparkan tentang (a) Deskripsi umum hasil penelitian, (b) Analisis deskriptif, (c) Analisis Kuantitatip dan Pengujian Hipotesis.

\section{a. Analisis Deskriptif}

Pada bagian ini penulis memaparkan mengenai skor rata-rata (mean) dan distribusi frekuensi data hasil keterampilan Berbicara bahasa Indonesia, yang diberikan perlakuan Jigsaw.

\section{1) Kelas JIGSAW (IV.A)}

Deskripsi data keterampilan berbicara bahasa Indonesia oleh siswa yang mengikuti pembelajaran model Jigsaw memiliki rentang skor $0-10$, n sebanyak 43 , skor minimum $=4$, skor maksimum $=10$. Rentang skor $=6$.
Tabel 4. Hasil Analisis Deskriptif

\begin{tabular}{|c|c|c|}
\hline \multirow{2}{*}{$\mathrm{N}$} & IValid & 43 \\
\hline & Missing & 0 \\
\hline \multicolumn{2}{|l|}{ Mean } & 7.49 \\
\hline \multicolumn{2}{|l|}{ Median } & 8.00 \\
\hline \multicolumn{2}{|c|}{ Std. DeIViation } & 1.919 \\
\hline \multicolumn{2}{|l|}{ IVariance } & 3.684 \\
\hline \multicolumn{2}{|l|}{ Range } & 6 \\
\hline \multicolumn{2}{|c|}{ Minimum } & 4 \\
\hline \multicolumn{2}{|c|}{ Maximum } & 10 \\
\hline
\end{tabular}

Statistics

Tabel 5. Distribusi Frekuensi Data Keterampilan Berbicara bahasa Indonesia yang Mengikuti Pembelajaran Jigsaw

\begin{tabular}{cccc}
\hline Nomor & $\begin{array}{c}\text { Rentang } \\
\text { Skor }\end{array}$ & Frekuensi & Kategori \\
\hline 1 & $3,6-4,5$ & 3 & Tidak terampil \\
\hline 2 & $4,6-5,5$ & 5 & $\begin{array}{c}\text { Kurang } \\
\text { Terampil }\end{array}$ \\
\hline 3 & $5,6-6,5$ & 6 & $\begin{array}{c}\text { Hampir } \\
\text { Terampil }\end{array}$ \\
\hline 4 & $6,6-7,5$ & 7 & $\begin{array}{c}\text { Cukup } \\
\text { Terampil }\end{array}$ \\
\hline 5 & $7,6-8,5$ & 7 & Terampil \\
\hline 6 & $8,6-9,5$ & 6 & $\begin{array}{c}\text { Terampil } \\
\text { Sekali }\end{array}$ \\
\hline 7 & $9,6-10$ & 9 & Sempurna \\
\hline
\end{tabular}

Siswa yang mengikuti pembelajaran dengan model Jigsaw sebanyak 43 responden dapat dilihat bahwa perolehan nilai kelas interval dengan rentang 3,6-4,5 pada nomor 1mencapai kategori tidak terampil 3 respoden $(7,0 \%)$; kelas interval 4,6-5,5 pada nomor 2 mencapai kategori kurang terampil 5 responden $(11,6 \%)$; kelas interIVal 5,6 - 6,5 pada nomor 3 mencapai kategori hampir terampil 6 responden $(14,0 \%)$; kelas interval 6,6 - 7,5 pada nomor 4 mencapai kategori cukup terampil 7 responden $(16,3 \%)$; kelas interval 7,6 - 8,5 pada nomor 5 mencapai kategori terampil 7 responden $(16,3 \%)$; kelas interval 8,6 - 9,5 pada nomor 6 mencapai kategori terampil sekali 6 responden $(14,0 \%)$; kelas interval 9,6-10 pada nomor 7 mencapai kategori sempurna 9 responden $(20,9 \%)$. Untuk hasil analisis deskriptif statistik dapat dilihat pada tabel berikut ini.

Tabel 6. Distribusi Frekuensi Data keterampilan Berbicara bahasa Indonesia hasil olahan statistik berikut ini. JIGSAW 


\begin{tabular}{ccccc}
\hline Valid & Frequency & Percent & $\begin{array}{c}\text { Valid } \\
\text { Percent }\end{array}$ & $\begin{array}{c}\text { Cumulative } \\
\text { Percent }\end{array}$ \\
\hline 4 & 3 & 7.0 & 7.0 & 7.0 \\
\hline 5 & 5 & 11.6 & 11.6 & 18.6 \\
\hline 6 & 6 & 14.0 & 14.0 & 32.6 \\
\hline 7 & 7 & 16.3 & 16.3 & 48.8 \\
\hline 8 & 7 & 16.3 & 16.3 & 65.1 \\
\hline 9 & 6 & 14.0 & 14.0 & 79.1 \\
\hline 10 & 9 & 20.9 & 20.9 & 100.0 \\
\hline Total & 43 & 100.0 & 100.0 & \\
\hline
\end{tabular}

Berdasarkan data tersebut di atas, dapat disimpulkan bahwa kelas interval 3,6 - 4,5 yang mencapai kategori tidak terampil 3 responden $(7,0 \%)$ mendapat nilai terendah, sedangkan kelas interval dengan rentang 9,6 - 10 pada nomor 7 mencapai kategori sempurna $(20,9 \%)$ mendapat nilai tertinggi. Untuk lebih jelasnya, dapat diperhatikan pada sebaran data berdasarkan daftar distribusi pada histogram gambar 01 pada halaman berikut ini.

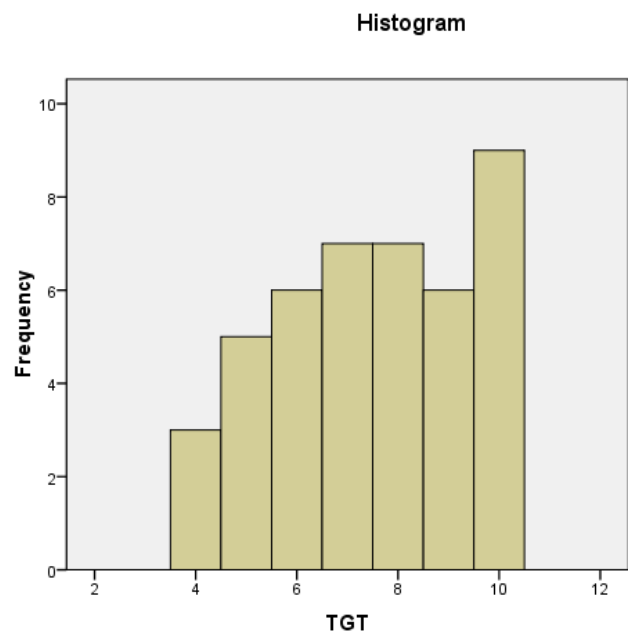

Mean $=7.49$
Std. Dev. $=1.91$
$N=43$

Gambar 1. Histogram Keterampilan Berbicara bahasa Indonesia Siswa yang Mengikuti Pembelajaran Dengan Model Jigsaw.

b. Analisis Kuantitatif dan Pengujian Hipotesis

Analisis kuantitatif digunakan untuk menghitung dan melakukan interpretasi terhadap data berupa angka-angka yang diperoleh siswa dari hasil posttest. Analisis kuantitatif adalah penerapan statistik inferensial untuk membaca hasil belajar keterampilan Berbicara bahasa Indonesia.

\section{1) Data Posttest}

a) Uji Normalitas

Pengujian hipotesis hasil analisis statistik inferensial untuk data hasil belajar keterampilan berbahasa Indonesia, dengan uji normalitas, uji homogenitas, dan uji t dapat diperhatikan pada pemaparan melalui statistik inferensial berikut ini. Pengujian data posttest ini dilakukan dengan menggunakan uji SPSS standar error 5\%.

Tabel 7. Case Processing Summary

\begin{tabular}{|c|c|c|c|c|c|c|}
\hline & \multicolumn{6}{|c|}{ Cases } \\
\hline & \multicolumn{2}{|c|}{ IValid } & \multicolumn{2}{|c|}{ Missing } & \multicolumn{2}{|c|}{ Total } \\
\hline & $\mathrm{N}$ & Percent & $\mathrm{N}$ & $\begin{array}{c}\text { Percen } \\
t\end{array}$ & $\mathrm{~N}$ & Percent \\
\hline JIGSA & 4 & 100.0 & 0 & $.0 \%$ & 4 & 100.0 \\
\hline W & 3 & $\%$ & & & 3 & $\%$ \\
\hline
\end{tabular}

Tabel 8. Tests of Normality

\begin{tabular}{ccccccc}
\hline & \multicolumn{3}{c}{$\begin{array}{c}\text { KolmogoroIV- } \\
\text { SirnoIV }\end{array}$} & \multicolumn{3}{c}{ Shapiro-Wilk } \\
\cline { 2 - 7 } & Statistic & df & Sig. & Statistic & df & Sig. \\
\hline JIGSAW & .134 & 43 & .051 & .917 & 43 & .004 \\
\hline a.Lilliefors Significance Correction & & &
\end{tabular}

b) Uji Homogenitas

Tabel 9. Test of Homogeneity of IVariances

Data

\begin{tabular}{cccc}
\hline LeIVene Statistic & df1 & df2 & Sig. \\
\hline .044 & 1 & 84 & .834 \\
\hline
\end{tabular}

Kriteria pengujian untuk uji homogenitas adalah kedua varian sama jika nilai $p$-Value $>\alpha$. Dari tabel di atas terlihat bawa nilai $p$-Value $=$ $0,834>\alpha$. Jadi dapat disimpulkan bahwa posttest memiliki Varians yang sama atau data tersebut homogen.

2) Uji T

Tabel 10 Independent Samples Test 


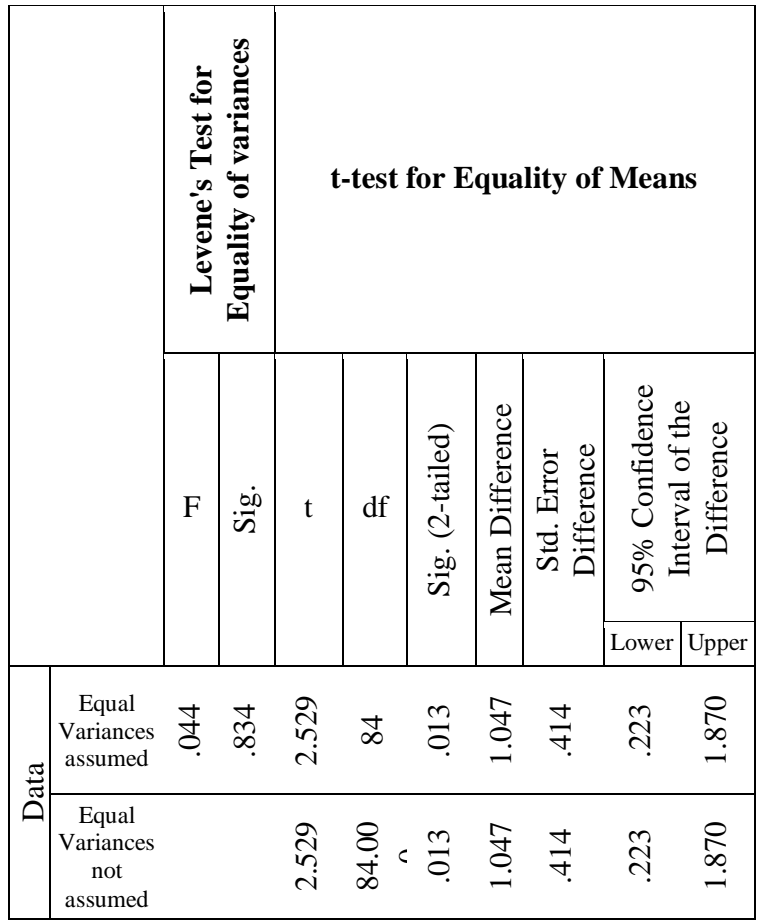

Hasil analisis SPSS diperoleh nilai t hitung untuk nilai posttest adalah 2,529. Dengan menggunakan tingkat keyakinan 95\%, $\alpha=5 \%$, dan dengan derajat kebebasan 84, diperoleh hasil $\mathrm{t}$ tabel sebesar 1,67. Karena $\mathrm{t}_{\text {hitung }}>\mathrm{t}_{\text {tabel }}$ $(2,529>1,67)$ maka $\mathrm{H}_{0}$ ditolak atau $\mathrm{H}_{1}$ diterima. Hal ini berarti bahwa nilai hasil belajar kelas yang diajar dengan Jigsaw memunyai pengaruh. Hasil analisis deskriptif menunjukkan adanya rata-rata hasil belajar kelas tersebut dan hal ini dipertegas oleh hasil analisis inferensial. Analisis deskriptif menunjukkan rata-rata hasil belajar siswa yang diajar dengan Jigsaw sebesar 7,49. Hal ini berarti rata-rata hasil belajar siswa yang diajar dengan Jigsaw lebih baik dibandingkan sebelum mereka diajar dengan model pembelajaran konvensional.

\section{KESIMPULAN}

Berdasarkan deskripsi hasil penelitian dan pembahasan pada bagian terdahulu, penulis menyimpulkan sebagai berikut: Terdapat pengaruh model pembelajatan Jigsaw, terhadap hasil belajar Berbicara bahasa Indonesia, kelompok siswa yang dibelajarkan dengan menggunakan perlakuan Jigsaw.

\section{DAFTAR PUSTAKA}

Arends, R.I. 1977. Laerning To Teack. Singapura: Mc Graw-Hill Book Campany.
Arends, R.I. 1998. Learning To Teack. New York: Mc Grow-Hill Companies, inc

Arends, R.I. 2007. Laerning To Teack, New York: Mc Grow-Hill Companies.

Arikunto, S. 1988. Penilaian Program Pendidikan. Jakarta: Dirjen Dikti Proyek Pengembangan lembaga Kependidikan.

Ausubel, D.P. 1974. Educational Psychology: A CognitiIVe IView. New York. Holt Rinehart and Winston.

Asri,A.S. I G A, 2011, Pengaruh Model Pembelajaran Kooperatif (JIGSAW \& JIGSAW, MotiIVasi Beprestasi dan Keterampilan social Terhadap Hasil Pembelajaran PKn Sekolah Dasar.Disertasi.UniIVersitas Negeri Malang.

Badan Penerbit UNM. 2010. Pedoman Penulisan Tesis dan Disertasi. Makassar: BP. UniIVersitas Negeri Makassar.

Badan Standar Nasional Pendidikan.2006. Panduan Penyusunan Kurikulum Tingkat Satuan Pendidikan Jenjang Pendidikan Dasar dan Menengah. Jakarta.

Budiono. 2010. Ejaan yang disempurnakan (EYD). Jakarta: Penerbit Bintang Indonesia.

Bendot, Tri Utomo, 2009. Pengaruh Metode Pebelajaran (Penemuan Terbimbing IVs Ekspositori) dan MotilVasi Berprestasi Terhadap Hasil Belajar Matematika pada Siswa Kelas IX SMP.Disertasi.PPS UM. Malang.

Bloom, B.S. et.al. 1982. Taxonomy of education ObjectiIVes.Handbook I; CognitiIVe Domain.New York McKay.

Confrey, Jere. (1995) A theory of intellectual deIVelopment. Journal for The Learning of Mathematics. Monograph, Number 15, June 1995, p,36-43. Canada: FLM Publishing Association.

Departemen Pendidikan Nasional 2007. Naskah Akademik Kajian Kebijakan Kurikulum SD, Pusat Kurikulum Badan Penelitian dan Pengembangan. Jakarta.

Degeng, I. N. S, 1989, Teori Pembelajaran: Taksonomi IVariabel. Jakarta: Program Magister Manajemen Pendidikan UniIVersitas Terbuka.

Degeng, I. N. S, 1997, Strategi Pembelajaran: Mengorganisasikan isi dengan Model Elaborasi. Malang: Penerbit IKIP Malang bekerja sama dengan Biro Penerbitan Ikatan Profesi Teknologi Pendidikan Indonesia Jakarta.

Degeng, I. N. S, 2001.Kumpulan Bahan Pembelajaran, Menuju Pribadi Unggul Lewat 
Perbaikan Kualitas Pembelajaran di Perguruan Tinggi. Malang. UniIVersitas Negeri Malang, LP3.

Dimyati,\& Mujiono. 2006. Belajar dan Pembelajaran. Jakarta: Rineka Cipta.

Gagne, R. M. 1977. The Condition of Learning. New York: Holt-Rinehart and Winston.

Gagne, R. M. \& Briggs, L. J. 1979.Principles of Instructional Design, second edition. New York: Holt-Rinehart and Winston.

Gunawan, 2010.Pendekatan Pembelajaran Bahasa Indonesia SD yang InoIVatif, Rumah Zakat Indonesia (RZI) Kota Cilegon.Blogspot. Com/2009/09/pendekatan-

pembelajaran/Jurnal Nasional, diakses tgl.17/8/2013. Pena Press.

Joyce, B, \& Weil, M; \& Calhoun, E; 2003.Models of Teaching ( $\left.7^{\text {th }} . e d\right)$. Boston: Allyn \& Bacon.

Joyce, B. \& Weil.M; \& Calhoun. 2011. Model of Teaching. Model-model Pengajaran. 8 th. Ed. Saduran. Fawaid, A \& A. Mirza. Pustaka Pelajar. Yogyakarta.

Kerlingger, F. N. 2000. Asas-asas Penelitian BehaIVioral.Terjemahan oleh Landung R. Simatupang. 1990. Jogyakarta: Gajah Mada UniIVersity Press.

Lie, A. 2002. CooperatilVe Learning: Mempraktekkan CooperatiIVe Learning di Ruang-ruang Kelas. Jakarta: Gramedia Widiasarana Indonesia.

Lie, A. 2008. CooperatilVe Learning: Paradigmas of Collega Teaching, http://faculyty, petra.ac.id.

Medsker, Keren L; Holdsworth, Kristina M. 2001.Models and Strategies for Training Design, New York: International Society for Performance ImproIV ement.

Poerwadarminta, W.J.S. 1979. Karang Mengarang, Yogjakarta, Penerbit Taman Siswa.

Pusat Bahasa. 2008. Kamus Bahasa Indonesia. Jakarta. Departemen Pendidikan Nasional.

Rusman, 2010.Model-model Pembelajaran Mengembangkan Profesionalisme Guru, seri Manajemen Sekolah Bermutu: Bandung. Rajawali Pers.

Sagala, S. 2007. Konsep dan Makna Pembelajaran. Bandung: Alfabeta.

Sanjaya, W. 2008.Strategi Pembelajaran Berorientasi Standar Proses Pendidikan. Kencana: Jakarta.

SlaIVin. R. E, 1977. Educational Psychology Theory and Practice. Allyn \& Bacon A Simon A. Scuster Company. Second Edition, Singapore.
SlaIVin, R. E, 1994.Educational Psychology: Theory, Research, and Practice. Boston: Allyn and Bacon.

SlaIVin, R. E. 1995.Centeren and ContructilVist Approaches to Instruction Second Edition, Boston: Allyn and Bacon.

SlaIVin, R. E. 2008.CooperatilVe Learning: Tiori, Riset, dan Praktik. Terjemahan oleh Nurulita, Bandung: Nusa Media.

Suhirman.2008. Pengaruh Metode Pembelajaran Kooperatif dan Keterampilan Sosial Terhadap Perolehan Belajar dan sikap social pada siswa Sekolah Dasar Kelas IV. Disertasi. Malang: PPS UniIVersitas Negeri Malang.

Surapranata, S. 2004. Analisis IValiditas, Reabilitas; dan Interpretasi Hasil Tes. Bandung: PT. Remaja Rosdakarya.

Trianto, 2007.Pembelajaran Kooperatif, (CooperatilVe Learning) Model-model Pembelajaran InoIVatif Berorientasi KonstruktiIVistik), Jakarta: Prestasi.

Tuckman, B.W, 1999. Conducting Educational Research. Fifth Edition: Orlando, Harcourt Brace College Publiher.

Undang-Undang Nomor 20 Tahun 2003.Tentang Sistem Pendidikan Nasional, Jakarta: Secretariat Negera RI.

Uno Hamzah B, 2009. Model Pembelajaran Menciptakan Proses Belajar Mengajar yang Kreatif dan Efektif. Jakarta: Bumi Aksara. 